\title{
The Use of Metaphors and Similes in Political Discourse in Ghana
}

\section{Emmanuel Amo Ofori, Charlotte Ogbedee Laryea, Benjamin Kubi, Vera Yayrah Fiawornu}

Department of Ghanaian Languages and Linguistics, University of Cape Coast, Cape Coast, Ghana

\author{
Email address: \\ eofori@ucc.edu.gh (E. A. Ofori)
}

\section{To cite this article:}

Emmanuel Amo Ofori, Charlotte Ogbedee Laryea, Benjamin Kubi, Vera Yayrah Fiawornu. The Use of Metaphors and Similes in Political Discourse in Ghana. International Journal of Language and Linguistics. Vol. 9, No. 4, 2021, pp. 180-187. doi: 10.11648/j.ij11.20210904.16

Received: June 15, 2021; Accepted: June 24, 2021; Published: July 8, 2021

\begin{abstract}
In this study, we examine how ordinary citizens use metaphors and similes in their contributions to political discussions in Ghana. We argue that the use of these figurative language devices is a subtle means by which citizens expose politicians and question their competence in handling national issues. They also serve as means of minimizing direct vilification of politicians in the political space of Ghana. In fact, when metaphors and similes are employed within a particular discourse, one has to understand the context in which they have been used as well as the specific communicative function they convey in order to arrive at the desired interpretation. Using Lakoff and Johnson's (1980) Conceptual Metaphor Theory, data collected from purposively selected and transcribed radio recordings as well as online commentaries, were critically analysed. The analysis revealed that ordinary citizens use metaphors and similes to surreptitiously expose the way and manner in which politicians run the country. Also, metaphors and similes serve as communication tools to mitigate the effect of otherwise direct attacks on politicians in Ghana. This study has implication for the relationship between political communication and society.
\end{abstract}

Keywords: Metaphor, Simile, Conceptual Metaphor Theory, Political Discourse, Ghana

\section{Introduction}

The relationship that exists between metaphors and similes is a subject of debate that has persisted from antiquity, and the debate seems unabated [8]. While some scholars maintain that metaphors and similes are similar, others argue that they are different [37]. For instance, on the assumption that any difference identified between the two tropes is only superficial, 'Aristotle held that metaphors are abbreviated similes,' [8]. Following from Aristotle's observation, comparison theorists such as $[34,14,13]$ have maintained that metaphors should be understood as implicit similes, [22].

Although there is widely held agreement that a metaphor and a simile express almost the same figurative meaning, there are also studies which have shown many differences between the two tropes, [42]. Citing other scholars, [42] notes the following differences between metaphors and similes: people prefer one form over the other, in which case the metaphor is preferred $[23,8]$; metaphors are comprehended faster than similes [16]; metaphors are interpreted as being more metaphorical and having force [16, 44]; metaphors are more likely to be used to make the discussion more interesting and to emphasize a point in conversation [38]; and metaphors are less likely to be used to compare similarities [21].

Whether similar or different, the importance of figurative language devices such as metaphor and simile in shaping public discourse, particularly political discourse, cannot be overemphasized, [5]. Indeed, [6, 7] has demonstrated that rhetorical devices such as metaphors "contribute to mental representations of political issues, making alternative ways of understanding these issues more difficult and in so doing 'occupy' the mind". [41] have also observed that metaphors help people to understand complex topics, communicate efficiently and influence others.

While the enterprise of studying metaphors in political discourse is receiving much attention from scholars, the concentration has been on elite discourse, and this may be because of the assumption that political leaders consciously use metaphors to convince or manipulate their audience [35]. On the other hand, however, as [35, 8] note, 'studying political discourse from a citizen perspective offers a bottomup way to tackle the question of how metaphors might impact on the citizens' framing of complex political processes'. It is 
on this score that we examine the use of metaphors, and by extension similes, by ordinary citizens in their contributions to political discussions on radio within the Ghanaian context.

\section{Literature Review}

A Metaphor is considered as a feature of figurative language [36] and thought to convey information from a source to a target, make a conversation more interesting and used in emphasis [42]. The concept of metaphors was previously thought to exist in poetic or novel expressions [26, 4]. This means that metaphors were only considered as features of language and not of thought. [27] have argued that metaphors are commonplace in everyday life and are used in indirect speech [31]. Psycholinguistic experiments have established that metaphors are cognitive concepts that are used in representations. These representations are commonly known as mappings which facilitate the comprehension of metaphors. These mappings enable the hearer or reader to relate the source to the target and vice versa. Hence, a source should map to a target or what it is meant to represent.

In the comprehension of metaphors, three main approaches have been discussed. These approaches aim to examine how the mappings involved in the processing of metaphors take place $[4,22,8]$. These approaches are the comparison model $[13,14,34]$, categorization model $[15,17-19,22]$ and the career of metaphor model [4]. Comparison theorists argue that metaphors express similarities and consider metaphors as elliptical similes. She is a vixen is considered as She is like a vixen. Comparison theorists further argue that there is a degree of similarity between the source and the target and the metaphor highlights this similarity however indeterminate it may be. This theory basically suggests that metaphors are property-matching mechanisms.

Categorization theorists also argue that "...metaphors establish taxonomic relationships between semantically distant concepts" [4, 3]. In comprehension, the source is used to derive an "abstract metaphorical category" of which it is a prototype and the target is assigned to this category. If a connection has previously been established between the source and the category, then it is accessed and the target is assigned to it. In my life is a circle, a circle refers to something which is endless, unidirectional or repetitive (category). Any feature that fits in this category can be associated with the target. The career of metaphor model is an integration of the two earlier models. It argues that new metaphoric expressions are processed as comparisons and after they become commonplace, they are processed as either comparisons or categorizations [4, 22, 8].

Culture and intertextuality have been established as relevant tools in the conceptualization and interpretation of metaphors $[1,45]$. Conceptualizations and interpretations are usually formed within a certain context and this means that an individual outside the context does not possess the relevant skills needed to comprehend a conceptualisation or conceptualise for people within that context. In excerpt 2, reference is made to a guinea fowl laying eggs and a situation with the government. Guinea fowls are birds which are native to Africa and an individual who has not lived in an African community with guinea fowls cannot conceptualize such a reference. Again, a person needs to possess a background knowledge (intertextuality) of happenings in the country in relation to governance to be able to conceptualize such a metaphor. [45] argues that examples cited by the Cognitive Theory of Metaphor are "historically motivated by experience" and a speaker will use a metaphor which is influenced by their experience as "members of a cultural group". This goes to support the assertion that the use of metaphors is rooted in ideology. These assertions do not take away from the fact that there are universals in the conceptualisation and interpretation of metaphors.

Previous studies have investigated the use of metaphors in public discourse $[5,30]$ and political communication $[12,9$, $28,40,29,45,3]$. [3] examined the use of conceptual metaphors to achieve the persuasive function of language and as an argumentative claim in political communication. The paper found that metaphors from the source domain of personification, reification and journey were mostly used in such instances. Again, these features were evident in claims of value which were mostly affirmative. Other studies have found that metaphors can be used to create distance and solidarity as is evident in [28] study, which analysed the use of metaphorical and metonymical references to conceptualizations in the Conceptual Metaphor Theory. Metaphors are also used in persuasive strategies in ideologically-positioned discourse [12]. Ideologicallypositioned discourse basically holds an $U s$ vs Them position and posits that one side is doing everything right and the other side is "evil" [43, 32, 33].

In a cross-cultural study aimed at investigating universal conceptual metaphors that were used to persuade and manipulate the public in political discourse, [40] investigated the source domain of metaphors in Croatian in relation to English and Italian. The study discovered that though metaphorical expressions differ from language to language, the same set of expressions occur in these languages. This goes to support the notion of culture-specific metaphors and intertextuality. An analysis of citizens' political discourse allows for the assessment of the impact of political issues on citizenry [35]. [35] applied [5] model of metaphor analysis to assess the use of deliberate metaphors by citizens to discuss the political situation in Belgium. The model was found to be effective in distinguishing between metaphors at the linguistic, conceptual and communicative levels. In this study, however, we argue strongly that ordinary citizens use comparisons as subtle means to expose politicians and question their competence in handling national issues. Also, they are means of mitigating direct vilification of political actors.

\section{Theoretical Framework: Conceptual Metaphor Theory}

Metaphors play a pivotal role in social and political reality 
constructions [27]. According to [29], our social experiences and conceptualizations are organized in terms of metaphors, and since politics forms part of the social domain, it must also be perceived and constructed metaphorically. It is against this backdrop that this study is grounded on Conceptual Metaphor Theory (CMT), pioneered by George Lakoff and Mark Johnson, in 1980, in their seminal study: Metaphors We Live By. Conceptual Metaphor Theory (CMT), sometimes called Cognitive Metaphor Theory, underlies the fact that "our ordinary conceptual system, in terms of which we both think and act, is fundamentally metaphorical in nature and it plays a central role in defining our everyday realities" [29, 3].

From the cognitive linguistics viewpoint, metaphor is understanding one conceptual domain in terms of another conceptual domain. This is conveniently captured as: CONCEPTUAL DOMAIN A is CONCEPTUAL DOMAIN $B[24,4]$. In other words, the conceptual domain A can be understood in terms of conceptual domain B. An example of a conceptual metaphor is ARGUMENT IS WAR. In this metaphor, the scenario of people having an argument is conceptualized to be similar to people fighting in a war. Thus various expressions and concepts commonly related to a war are used when discussing an argument. For [20], the most fundamental notion of CMT is mapping, which refers to a systematic correspondence between closely linked ideas. Mapping gives rise to two main types of conceptual domains: the source domain and the target domain. Whereas the source is "the domain supporting the literal meaning of the expression", the target domain is "the domain the sentence is actually about" $[10,195]$. For instance, in the expression, "I invested a lot of time in her", 'time' is the target domain since it is the idea expressed in the sentence. Correspondingly, 'money' is the source domain because it is the concept employed in describing an idea, 'time'. Additionally, source domains are typically concrete, physical, simple, familiar and well- delineated concepts while target domains are usually abstract, complex, unfamiliar and less delineated [24, 39]. Taking 'time' and 'money 'into consideration, 'money' is physical and concrete, while 'time' is complex and abstract.

Conceptual Metaphor Theory has some principles, constraints and hypotheses that define it. They are: «Unidirectionality of Metaphor», «Hiding and Highlighting» and «Invariance Principle». The first among them which is «Unidirectionality of Metaphor», asserts that conventionally, source domains can structure target domains, but not vice versa. Thus, whereas target domains like ARGUMENT can be understood in terms of WAR, the reverse is not the case. The second hypothesis «Hiding and Highlighting» claims that in a metaphor, only an aspect of a target concept is brought to the fore (highlighted) by the source, leaving out (hiding) other aspects of the target simultaneously. For instance, only the adversarial quality of war is highlighted in the metaphor ARGUMENT IS WAR, hiding other aspects like the fact that arguments can sometimes be peaceful [11]. The most controversial of the hypotheses is the «Invariance Principle» [25]. This principle puts restriction on the kind of source domain that can structure the target domain. Thus, although according to the theory, concrete concepts serve as source domains, target domains select the kind of source domains that can structure them. For instance, it is argued that, while DEATH can be structured in terms of agents like DEVOURER, REAPER in a metaphor like DEATH IS A DEVOURER/ REAPER, it cannot be structured in terms of agents like LECTURER, COOK in an unattested metaphor like DEATH IS A LECTURER/ COOK [2].

\section{Data Collection Method}

The data for this study were obtained mainly from recordings of phone-ins on radio, complemented with online commentaries, specifically on political discussions. The period for the gathering of the data span from 2012-2014. We adopted purposive sampling technique to identify the various instances of metaphors and similes on radio phone-ins and online commentaries which were germane to the current study. Three radio stations were selected in Accra, (Adom FM, Peace FM, and Happy FM). We selected these three radio stations because of their widespread coverage. That is, these stations have affiliate radio stations as well as communication centers spread across the length and breadth of Ghana, which provides listeners, especially Ghanaian both home and abroad the opportunity to either text or phone-in to put their message across. In addition, most of their political programs and discussions are broadcast in Akan and this afford ordinary citizens the opportunity to contribute to such political discussions via phone-ins. In all a total of fifty (50) phone-ins were randomly recorded, sampled, transcribed and analyzed, using [27] Conceptual Metaphor Theory.

In addition, data were gathered from three online websites to complement the recorded phone-in data on radio. These are: www.peacefmonline.com, www.ghanaweb.com, and www.myjoyonline.com. We specifically selected these online portals because they have maintained certain standards over the years and have been deemed to be credible with their reportage.

\section{Analysis and Discussions}

In this section we conduct a thorough analysis of how ordinary citizens use metaphors and similes to contribute to political discussions in Ghana. Employing these comparisons, we discuss the subtle means by which citizens expose politicians and question their competence in handling national.

Excerpt 1

1) [Background: The discussion was focused on the accountability of government. Below is a contribution from an ordinary citizen.]

2) Burning issues-Adom FM October 142013

3) Me nuabaa, me dec, nnecma bi wo kurom ha seesei a

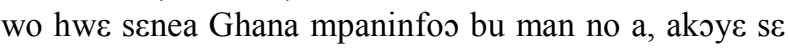
baakofoo a wate n'asore na ogye collection no a na kaa V8 na waksto. Control board see koraa na wasan aba 
asoredan mu ho na wabchye nkom na wagye sika ato control board.

4) 'My sister, as for me, currently, there are a lot of things happening in this country, currently if you look at the way Ghanaian leaders are governing the country, it is like a sole owner of a church who takes his/her own collection/offering and buys a V8. When the control board (of the V8) is not working, he prophesies to the church for money to buy a control board.'

Table 1. Caller's simile.

\begin{tabular}{ll}
\hline Source & Target \\
\hline Sole owner of church/prophet & Ghanaian leaders/leaders in government \\
Church members & Ghanaian people \\
\hline
\end{tabular}

The table above shows one-to-one mapping of source to target. The sole owner of the church/prophet maps onto the domain of leaders in government and the church members maps to all Ghanaians. The caller's simile indicates the way the country is being run by the leaders who consistently increase taxes with the aim of salvaging the ailing economy. When those taxes are misused or misapplied, they come back and introduce more taxes. The use of the word baakofor "one man" and expression hys nkom "prophecy," which maps to the leaders interestingly could be used to explicate insults in a culturally insightful way because Ghana is experiencing an era of one-man churches (sole owner of a church), who give all sorts of prophecies to extort money from gullible church members. The prophets live in mansions, drive the most expensive cars (not forgetting the caller's mention of V8), wear expensive clothes, and eat the best food while their members live in abject poverty. The picture being presented here is that Ghanaian leaders are cunning cheats, who have no regard for tax-paying citizens. The physical experience of a church-prophet and members provide us with the way Ghanaian leaders are governing the country and how ordinary citizens respond to it. It is important to mention that the caller criticizes Ghanaian leaders, but this is presented nicely in a form of simile, which exposes the deceitful nature of those on the helm of affairs in the country.

Excerpt 2

1) [Background: The discussion was focused on how to assist government workers and politicians to achieve a better Ghana. Below is a contribution from an ordinary citizen]

2) Adom FM (Burning issues) October 23, 2013

3) Yoo. Sister Afia meda wo ase. Sister Afia, time no a yesua no, ye taa ko wia obi akomfem oto wo nwuram a, cbi a motete a sto baako na moaksfa; sto baako a na moakofa. Na yetaa wiawia. ebi na John Mahama amammuo no aye.

4) Okay Sister Afia. Sister Afia, when we were young, we used to steal the eggs of someone's guinea fowl in the bush. We hide in the bush, when it lays an egg we go and take it; it lays an egg we go and take it. We were stealing them. That is what John Mahama's government is doing.
Table 2. Caller's metaphor.

\begin{tabular}{ll}
\hline Source & Target \\
\hline Young People & Politicians \\
Guinea fowl & Ghanaian people \\
Egg of guinea fowl & Government resources \\
\hline
\end{tabular}

The table 2 shows a one-to-one mapping of source to target. The young people map onto politicians; the guinea fowl maps onto the Ghanaian people; and the egg of the guinea fowl maps onto government coffers. The caller's metaphor implicitly shows the manner in which politicians are stealing from the coffers of the country. The idea of young people hiding and stealing every egg the guinea fowl lays is interesting because it relates to how politicians steal every cedi that goes into government coffers. It insinuates that politicians generate a lot of money by taxing the people of Ghana, and later turn around and steal those monies. Therefore, the caller presents politicians as thieves, stealing from the coffers of Ghanaians. The caller insults politicians but in a presentable way captured in a form metaphor that exposes their thievery. The caller's metaphor poses a challenge to political authority to desist from stealing the people's money.

Excerpt 3

1) [Background: On January 7, 2014 the President of the Republic of Ghana met the Press to answer questions on his first term in office. After the meeting, Happy FM had a discussion on it during which callers were asked to contribute to the program. Below is an exchange between the host of the program and an ordinary citizen.]

2) Happy FM (Yepe a yebshu)

3) $\varepsilon m r \varepsilon$ aso se NDCfos эomo bedi akonwa эomo nka nokware na Ghana ntu mpon na se Ghana betu mpon a

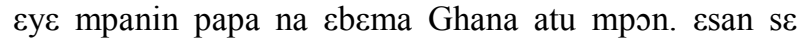
opanin, ontumi mmegye tax, enye road toll, enye biribiara na ommeka nkyere Ghanafoo se yenni sika. Yenni sika a yede bebo oman no ho bra. Enti court case nti na woantumi ammu man. Meanwhile radio stationfoo moantua tax? Ne nyinaa ogye ye. Wotease $\varepsilon$ ?

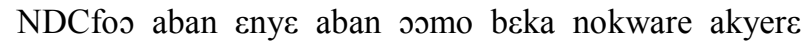

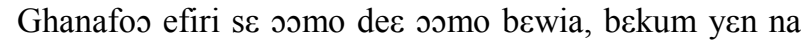

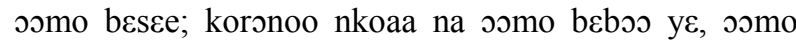

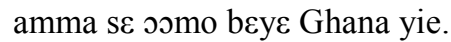

4) "It is time for the ruling NDC government to be truthful to Ghanaians. The progress of Ghana depends on good leaders. The reason being that the leaders cannot take taxes, road tolls and others and tell Ghanaians that there is no money. We don't have money to run the governance the country. So you could not govern the country because of the court case. Meanwhile radio stations, didn't you pay taxes? They took all the taxes. Do you understand? The NDC government will never be truthful to Ghanaians because as for them they have come to steal, to kill and to destroy. They ascended the throne only to steal from us. They did not come to power to develop Ghana."

The ordinary citizen uses a metaphor similar to the Bible's 
description of a "thief" to refer to the NDC government. The Bible's description is found in John 10: 10a, which states, "The thief comes only to steal, kill and destroy" (New International Version). The ordinary citizen portrays the NDC government as thieves, who are only in power to steal, kill and destroy. The NDC government is not only presented as thieves, but is considered something more, as in the Bible, "the thief" refers to "Satan," the devil," as well as an "enemy of progress." The use of the word "steal" may literally mean stealing from the coffers of the government. However, "kill" and "destroy" involve depriving Ghanaians of the better life they want to enjoy. If there is no money in the coffers of the government, it will ultimately affect the economy and the consequences will be on the Ghanaian people.

The caller's relation of this metaphor to the Bible is very instructive because Ghana is a country where the majority are Christians. Making such a relation may likely resonate with a lot of people who will take his comments as sacrosanct. Again, the host of the program will not chide the caller for an unsavory comment but will treat it as a quotation from the Bible. In sum, the ordinary citizen criticizes political authority, but this is done religiously to challenge political authority to be truthful and develop the country for the benefit of all Ghanaians.

Excerpt 4

1) Adom FM (Burning issues) October 21, 2013

2) [Background: The discussion was focused on how to assist government workers and politicians to achieve a better Ghana. Below is a contribution from an ordinary citizen.]

3) Afia: Yenko Abaana ho wo Adenta. Bra Abaana, good evening.

4) Lets talk to Abaana in Adenta. Brother Abaana, good evening

5) Abaana: Meregye wo so, Afia Pokuaa.

6) I respond Afia Pokuaa.

7) Afia: Boss mepaakyew wo wo air, wae.

8) Boss please you are on air.

9) Abaana: Yoo Afia. Na apow mu te sen?

10)Okay, Afia. And how are you?

11)Afia: Bokso.

12)Cool (I'm doing very well).

13)Abaana: Adwuma no de $\varepsilon$ worebo. Obi ara pe w'asem wo Ghana ha.

14)You're doing a great job everyone likes you in Ghana.

15)Afia: Medaase boss.

16)Thank you boss.

17)Abaana: emmarima nuabaa baako $\mathrm{p} \varepsilon$.

18)The only sister of men.

19) Na Afia pokuaa, woahu se saa kasa wei nyinaa $\varepsilon y \varepsilon$ arrogance, woahu. Sebe o, wone wo yere te na $s \varepsilon$ wo nni sika a wode bo ne akonhoma da bi na se wopea ne

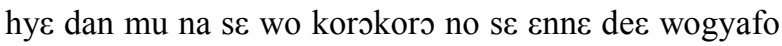

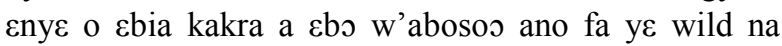
menkəp $\varepsilon$ bi mmra anaa biribi saa ontease $\varepsilon$. Na $s \varepsilon$ kəm

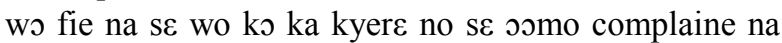

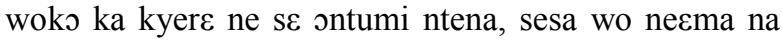

ko a, sesa wo necma na firi fie ha ontumi ntena aware $\varepsilon$ no ase a, se ntokwa na woakofa aba fie.

20)Afia Pokuaa, have you noticed that all these talks are arrogance, have you seen that? Excuse me to say, if you live with your wife and you don't have house-keepingmoney for her, what you do is that you take her to the room and persuade her that today I don't have money, so if she has some small money she should use it instead, I'm going out to struggle for some money and things like that, won't she understand? But if there is hunger in the house and you tell her that she is complaining too much, if she cannot continue with the marriage then she should pack bag and baggage and leave, you have created a big fight.

Table 3 Ordinary citizen's simile.

\begin{tabular}{ll}
\hline Source & Target \\
\hline Husband & President/the government (employer) \\
Wife & Ghanaian workers (employees \\
House-keeping-money & Government coffers \\
\hline
\end{tabular}

Table 3 above shows a one-to-one mapping of source to target. The husband maps onto the president/the government (employer); wife maps onto the Ghanaian workers (employee) and house-keeping-money maps onto government coffers. The ordinary citizen's simile provides us with the idea of the family system in Ghana where the husband is the head and the breadwinner of the family. It also shows the social contract that exists between husbands and wives, and the husband's effective persuasive tool of convincing the wife when his role of ensuring that there is money to run the affairs of the house is not met. Relating this simile to the frosty relationship that exists between the government of Ghana and Ghanaian workers concerning the payment of allowances, the citizen reveals government inability to convince or persuade workers when the contract between them is breached (when government does not have money to pay the workers); rather, resort to infuriating the workers the more. Therefore, the citizens' simile presents us with the government's poor communication in terms of the handling of the workers agitation on their allowance.

Ordinary citizens' metaphors of disorder and the economy

The economy of every country is the pivot around which other things such as health, education, security and others revolve. When the economy is not doing well, it is natural for citizens to express their frustration because it directly affects their daily living. In view of this, citizens in Ghana use metaphors of disorder to challenge the existing political authority to fix the ailing economy as exemplified in excerpts 5 and 6.

Table 4 Caller's simile.

Caller's Simile

\begin{tabular}{ll}
\hline Source & Target \\
\hline Parked Car & Economy \\
Novice Driver & President \\
Children & Ghanaian people \\
\hline
\end{tabular}


In excerpt 4, the ordinary citizen uses two figurative expressions to describe the economy. The first one, as shown in table 4 , is a simile that relates the economy to a parked car with a novice driver: the parked car mapped onto the economy, the driver mapped onto the president and the children mapped onto Ghanaian people. His simile provides us with a picture of a president who does not know how to manage the economy, and therefore leads the whole country into a ditch. He compares the rate of the Ghanaian cedi to other currencies to show the bad state of the economy. What really bothers him is how the CFA is outperforming the cedi.

The second figurative expression, in excerpt 5, is a metaphor in which the citizen mirrors the economy to a patient who is on admission at Korle $\mathrm{Bu}$ hospital (the biggest teaching hospital in Ghana). It is interesting to note that "Korle Bu" is a referral hospital (a hospital that provides tertiary care, which is health care from specialists in a large hospital after referral from primary or secondary care), so if an economy is on admission at a referral center, it tells the severity of the "ailment" of the economy. Meaning all the other hospitals, being primary or secondary care facilities (i.e. economic experts) in Ghana could not heal or offer the best cure for the ailing economy. The ordinary citizen further points to the fact that the economy will soon be sent to the morgue, indicating how fragile the economy is. If the economy will soon land at the morgue then it is metaphorically presented that it is on the verge of dying or collapsing.

Thus, the ordinary citizen's simile and metaphor on the economy is a challenge to the president to fix the economy because Ghanaians are suffering. His comment also questions the president's handling of the economy; that is to say, the president is not managing the economy to the satisfaction of the citizens.

Similarly, in excerpt 6, the metaphor "Ghana's economy is out of control" presents us with an idea of the current state of the economy. To the ordinary citizen, everything is completely out of gear in the country since state institutions are arbitrarily doing what they want. This is captured in his chronicle of some institutions collecting tolls and others increasing tariffs and bills at will without consulting the presidency, thus pointing to the fact that the president is not in control of the administration of the country. Therefore, this metaphor shows the disorder in the country; nothing seems to be working.

In general these metaphors of disorder show the kind of choices citizens make in their discourse by comparing the economy and political leadership to parked cars and novice drivers, and, most importantly, linking the ailing economy to a patient on admission at a referral hospital (Korle $\mathrm{Bu}$ hospital) waiting to be conveyed to the morgue. Also, the economy is represented as completely out of control. These representations, to some extent, present us with the understanding of a country whose economy is totally in a mess, needing redemption or in the economic world require a "bail out." Further, political leadership and economic experts are represented as inept in terms of mapping out proper strategies to salvage the ailing economy. Some of the citizens' comments present a gloomy picture of a country where nothing seems to be working; and everyone seems to be doing what he or she wants, showing the confusion and how things are disorganized in the country. There is no leadership in the country as presented in the citizen's simile in excerpt 4, table 4; the president does not even have the leadership abilities to manage the economy.

Excerpt 5

1) [Background: The host of the program opens the phone lines after every morning political discussion to solicit the views of the citizens on the economy. Below is a comment from a citizen.]

2) Kokrooko (peacefm) September 202013

3) Kwame: Abacha wo ahoma no so. Abacha yema wo akye.

4) Abacha is on the line. Abacha, good morning.

5) Abacha: Yaa Bra Kwame, ete scn?

6) I respond, Brother Kwame. How are you?

7) Kwame: Nyame wo ho

8) God exists.

9) $\mathrm{Na}$ bra Kwame, mesan ako m'asem no so bio. Seesei Ghana yerehu amane papapaa. Yebesre omanpanin, Bro Kwame, economy $\varepsilon$ te $s \varepsilon$ kaa a $\varepsilon s i$ fie na akoy $\varepsilon$ s sebe, scbe wo papa onnim kaa ka na woaks foro, obeks akskum mo. Seesei ychwe baabi a dola, euro, seesei koraa cefa koraa a ye ne no te Africa ha no koraa ono ste kaa no front $\varepsilon$ na ode yen koro. Enti yebesre omanpanin $\mathrm{s} \varepsilon$ seesei ye economy no na $\varepsilon$ da Korle Bu a seesei $\varepsilon y \varepsilon$ aduru mokyere. onhw $\varepsilon$ na ony $\varepsilon$ biribi mfa ho mma yen because Ghanafoo yerebre.

10)Brother Kwame, I'll revisit my issue again. Currently, Ghanaians are suffering. We would like to plead with the president, brother Kwame; economy is like a parked car in a house, excuse me to say, your father does not know how to drive and jumps into the car; he'll go and kill all of you. Currently, if you look at the rate of the dollar, euro and even the CFA in Africa is seated at the front of the car driving. So, we want to plead with the president to tell us if our economy is on admission at Korle $\mathrm{Bu}$ and it will soon be sent to the morgue. He should do something about it for us because Ghanaians are suffering.

Excerpt 6

1) [Background: The comment below is a response to an article written by Professor Lord Amoah of Ashesi University, accusing politician of thinking of the masses as "idiots" and "fools."]

2) Author: Just being curious!!

3) Date: 2014-02-09 05:10:08

4) Source: Ghanaweb

5) Comment to: Our leaders think us 'idiots', 'fools'-

6) Ghana's economy is completely out of control, with everybody doing his or her own thing. President Mahama is simply useless. Mahama cannot control anything or anybody in corporate Ghana, even including his family members, because he knows his 
corrupt lazy visionless ways. Yesterday, it was the University of Ghana authorities introducing toll charges for use of the university roads. Another time, it was the Electricity Company of Ghana (ECG) increasing electricity tariffs. Another time, it was the Water Company introducing water meters and increasing water consumption bills. Another time, it was petroleum companies increasing fuel retail prices.

\section{Conclusion}

In this paper, it has become evident that ordinary citizens utilize metaphors and similes to subtle criticize politicians and question their competence in handling national issues. Indeed, the analysis has also revealed the level to which citizens employ these comparisons to mitigate the effect of direct vilification and attacks on politicians in political discourse in Ghana. In fact, the use of metaphor and simile enhances citizens' participation in the day-to-day political discussions and contribute to the deepening of multiparty democracy in Ghana, without resorting to insults and vituperations. The application of Conceptual Metaphor Theory presents us with the physical experience of events that exist within the society and how citizens manipulate and respond to those issues to suit their communicative purposes. The analysis of metaphor of disorder reveals an interesting phenomenon in terms of the diction of citizens to compare economies to unmovable cars and inexperienced drivers as well as bad economies to patients admitted at the hospital, presents a broader idea of the in-depth knowledge and understanding of ordinary citizens with respect to the happenings in the country.

\section{References}

[1] Ansah, G. N. (2010). The culture of conceptual metaphors: the case of emotions in Akan and English. Papers from Lancaster University Postgraduate Conference in Linguistic \& Language Teaching, pp. 2-25.

[2] Asante, R. K. \& Ma, Q. (2015). Metaphtonymies in Akan. Acta Linguistica: Journal of Contemporary Language Studies, $9(1), 82-97$.

[3] Borčić, N., Kanižaj, I. \& Kršul, S. (2016). Conceptual metaphor in political communication. Proceedings of the University of Dubrovnik, 3, pp. 73-94.

[4] Bowdle, B. \& Gentner, D. (2005). The career of metaphor. Psychological Review, 112 (2), 193-216.

[5] Burgers, C., Konijn, E. A. \& Steen, G. J. (2016). Figurative framing: Shaping public discourse through metaphor, hyperbole, and irony. Communication Theory, 26, 410-430. doi: 10.1111/comt.12096.

[6] Charteris-Black J. (2011) Metaphor in Political Discourse. In: Politicians and Rhetoric. London: Palgrave Macmillan. https://doi.org/10.1057/9780230319899_2.

[7] Charteris-Black, J. (2004). Corpus approaches to critical metaphor analysis. Basingstoke: Palgrave Macmillan.
[8] Chiappe, D. L. \& Kennedy, J. M. (2000). Are metaphors elliptical similes. Journal of Psycholinguistics Research, vol. 29, No. 4.

[9] Cienski, A. (2005). Researching conceptual metaphors that (may) underlie political discourse. ECPR Workshop on Metaphor in Political Science, pp. 1-18.

[10] Croft, W. \& Cruse, A. D. (2004). Cognitive linguistics. Cambridge: Cambridge University Press.

[11] Evans, V. \& Green, M. (2006). Cognitive linguistics: An introduction. New York: Oxford University Press.

[12] Ferrari, F. (2007). Metaphor at work in the analysis of political discourse: investigating a 'preventive war' persuasive strategy. Discourse and society, vol. 18 (5): 603-625.

[13] Fogelin, R. (1988). Figurative Speaking. New Haven, Connecticut: Yale University Press.

[14] Gentner, D. (1983). Structural-mapping: a theoretical framework for analogy. Cognitive Science, 7, 155-170.

[15] Glucksberg, S. (2001). Understanding figurative language: From metaphors to idioms. London, UK: Oxford University Press.

[16] Glucksberg, S. (2003). The psycholinguistics of metaphor. Trends in Cognitive Science, 7 (2): 92-96.

[17] Glucksberg, S. \& Haught, C. (2006a). Can Florida become like the next Florida? When metaphoric comparisons fails. Psychological Science, 17, 935-938.

[18] Glucksberg, S. \& Haught, C. (2006b). On the relation between metaphor and simile? When comparisons fails. Mind and Language, 21, 360-378.

[19] Glucksberg, S. \& Keysar, B. (1990). Understanding metaphorical comparisons: Beyond similarity. Psychological Review, 97, 3-18.

[20] Grady, J. E. (2007). Metaphor. In D. Geeraerts \& H. Cuyckens (Ed.), The Oxford handbook of cognitive linguistics, (pp. 188213). New York: Oxford University Press.

[21] Harris, R., Firel, B., \& Mickelson, N. (2006). Attribution of discourse goals for using concrete- and abstract-tenor metaphors and similes with or without discourse context. Journal of Pragmatics, 38 (6), 863-879.

[22] Haught, C. (2013). A tale of two tropes: How metaphor and simile differ. Metaphor and Symbol, 28 (4), 254-274. DOI: 10.1080/10926488.2013.826555

[23] Kennedy, J. M. \& Chiappe, D. L. (1999). What makes a metaphor stronger than a simile? Metaphor and Simile, 14, 6369.

[24] Kövecses, Z. (2010). Metaphor: A practical introduction $2^{\text {nd }}$ ed. Oxford: Oxford University Press Inc.

[25] Lakoff, G. (1990). The invariance hypothesis: Is abstract reason based on image schemas? Cognitive Linguistics 1: 3974 .

[26] Lakoff, G. (1992). Metaphor and war: The metaphor system used to justify war in the gulf. In M. Putz (ed.), Thirty Years of Linguistic Evolution: Studies in Honor of Rene Driven on the Occasion of His Sixtieth Birthday. Amsterdam: John Benjamins. pp. 463-481. 
[27] Lakoff, G. \& Johnson, M. (1980). Metaphors we live by. Chicago: University of Chicago Press.

[28] Meadows, M. (2007). Distancing and showing solidarity via metaphor and metonymy in political discourse: a critical study of American statements on Iraq during the years 2004-2005. Critiacl Approaches to Discourse Analysis across Disciplines $1(2): 1-17$.

[29] Musolff, A. (2004). Metaphor and political discourse: Analogical reasoning in debates about Europe. Basingstoke, U.K.: Palgrave Macmillan.

[30] Norocel, C. O. (2013). Give us back Sweden! A Feminist reading of the (re)interpretation of the Folkhem conceptual metaphor in Sweden radical right populist discourse. NORANordic Journal of Feminist and Gender Research, 21: 1, 4-20.

[31] Obeng, S. G. (1997). Language and politics: Indirectness in political discourse. Discourse and society. (1): (p 49-83).

[32] Ofori, E. A. (2015). The use of Insults in Ghanaian Political Discourse: A Critical Discourse Analysis (Ph.D. Dissertation). University of Florida, Gainesville, U.S.A.

[33] Ofori, E. A. (2018). Inter-party insults in political discourse in Ghana: a Critical Discourse Analysis. In Jason Kandybowicz, Travis Major, Harold Torrence \& Philip T. Duncan (eds.), African linguistics on the prairie: Selected papers from the 45th Annual Conference on African Linguistics, 21-35. Berlin: Language Science Press.

[34] Ortony, A. (1979). Beyond literal similarity. Psychological Review, 86, 161-180.

[35] Perrez, J. \& Reuchamps, M. (2014). Deliberate metaphors in political discourse: The case of citizen discourse. Metaphorik.de, 25, 7-41. https://www.metaphorik.de/sites/www.metaphorik.de/files/jou rnal-pdf/25_2014_perrez-reuchamps.pdf.
[36] Pierce, R. S. \& Chiappe, Dan, C. L. (2008). The roles of aptness, conventionality, and working memory in production of metaphors and similes. Metaphor and symbol, 24: 1, 1-19.

[37] Richardson, J. (2007). Analyzing Newspapers: An Approach from Critical Discourse Analysis. Houndmills: Palgrave.

[38] Roberts, R. \& Kreuz, R. (1994). Why do people use figurative language? Psychological Science, 5 (3), 159-163.

[39] Semino, E. (2008). Metaphor in discourse. Cambridge: Cambridge University Press.

[40] Stojan, N. \& Mijic, N. S. (2019). Conceptual metaphors in political discourse in Croatian, American and Italian Newspapers. Academic Journal of Interdisciplinary Studies, vol. 8 (1), pp. 69-76.

[41] Thibodeau, P. H., Matlok, T. \& Flusbery, S. J. (2019). The role of metaphor in communication and thought. Language and Linguistics Compass, 1-18. DOI: 10.1111/lnc3.12327.

[42] Utsumi, A. (2007). Interpretive diversity explains metaphorsimile distinction. Metaphor and Symbol, 22 (4), 291-312. DOI: $10.1080 / 10926480701528071$.

[43] van Dijk, T. (1995). Discourse analysis as ideology analysis. Language and peace, 17-33. Aldershot: Dartmouth Publishing.

[44] Zharikov, S. \& Grentner, D. (2002). Why do metaphors seem deeper than similes? In proceedings of the $24^{\text {th }}$ Annual Meeting of the Cognitive Science Society (pp. 976-981). Fairfax, VA: Cognitive Science Society.

[45] Zinken, J. (2003). Ideological imagination: intertextual and correlational metaphors in political discourse. Discourse \& Society, pp. 507-523. 